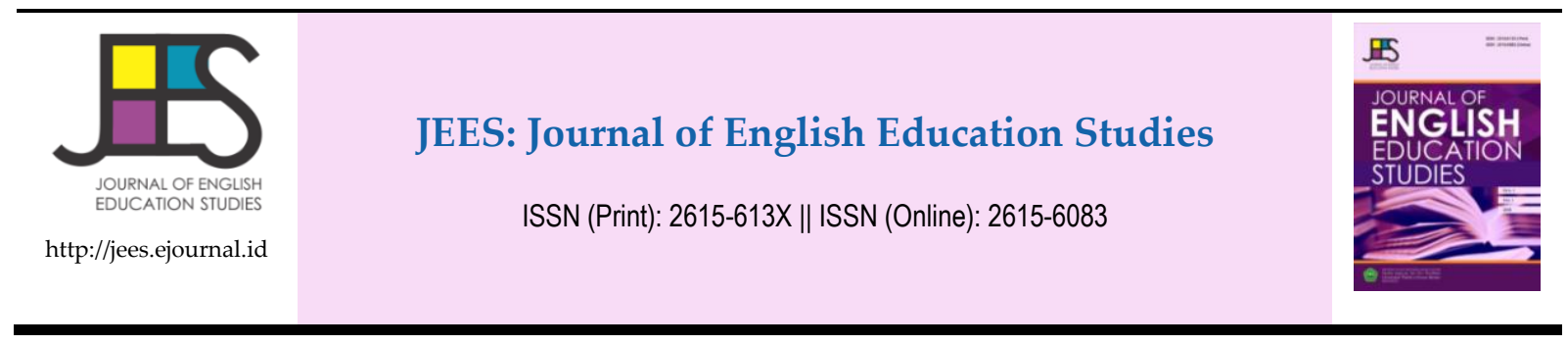

\title{
Student Teachers' Acceptance towards Blended Learning in Teaching and Learning Psycholinguistics
}

\author{
Rosmania Rima ${ }^{1}$
}

${ }^{1}$ English Education Study Program of Teacher Training and Education Faculty, Universitas Sultan Ageng Tirtayasa

\begin{tabular}{l} 
ARTICLE INFO \\
\hline Keywords: \\
students' acceptance \\
blended bearning \\
face to face learning
\end{tabular}

\begin{abstract}
This study aimed at examining student teachers' acceptance toward blended learning in teaching and learning Psycholinguistics. It focuses on students' attitudes toward using SPADA at spada.untirta.ac.id as learning management system combined with face to face learning. The survey involves 118 undergraduate students enrolled in Psycholinguistics course of English Department Untirta. Technological Acceptance Model (TAM), questionaire and interview are used to obtain the data. The learners' acceptance toward the blended learning in Psycholinguistics course in overall is at a very good level, including the perceived usefulness and the perceived ease of use. For further research, it is suggested to explore the factors that influence teachers' acceptance with blended learning and the proportion between online and face to face learning.
\end{abstract}

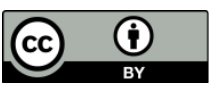

This is an open access article distributed under the terms of the Creative Commons Attribution 4.0 International License, which permits unrestricted use, distribution, and reproduction in any medium, provided the original work is properly cited. (c) 2020 Rosmania Rima

\section{INTRODUCTION}

Blended learning is a term that refers to the blending of traditional learning methods and new learning methods based on e-learning. Recently, blended learning has gained considerable popularity in education, especially in college or unversity. University of Sultan Ageng Tirtayasa (Untirta) has launched Learning Management System known as SPADA to implement blended learning among their students. Blended learning also has been acknowledged and practically initiated in Untirta as one of the approaches to conduct teaching and learning processes. To ensure the blended learning approach is successfully implemented, students' and lecturers' involvement is monitored in committed blended learning for the courses in every semester.

The face to face and e-learning programs can both support and hinder student success in learning. Face to face classrooms can create safe and flexible learning environments where caring instructors and tutors help students gain the necessary confidence to thrive (Pross \& Barry, 2004). On the other hand, the lack of instructor response to student learning needs or poor class attendance due 1 Corresponding author's adress: English Education Study Program of Teacher Training and Education Faculty, Universitas Sultan Ageng Tirtayasa, Banten,
Indonesia

e-mail: rosmania@untirta.ac.id 
to time demands and family responsibilities (Zacharakis et al., 2011) can have a significant negative impact on student outcomes.

Blended learning, an instructional approach that includes face to face instruction with an online component, has the potential to provide students with support and encouragement through enhanced interaction, while accommodating individual challenges such as time, family, commuting, and learning pace, via a flexible online platform. Garrison and Kanuka (2004:97) point out that true blended learning is a meaningful integration of face to face and online components to provide students with engaging learning experiences that serve their "various specific contextual needs".

The teaching and learning Psycholinguistics course in the third year students has implemented blended learning as recommended by the unversity. It promotes learning which is directed to be student-centered with the expected learning outcomes as the focus. Student centered states that graduate learning outcomes are achieved through learning processes that prioritize the development of creativity, capacity, personality, and needs of students, as well as developing independence in seeking and finding knowledge. Students must be encouraged to have motivation in themselves, then strive to achieve the desired learning outcomes.Moreover, higher education students have benefited from blended learning environments because it promotes social-constructivist pedagogy, addressing different learning needs, and building collaborative communities (Hoskins, 2012; Packham, Jones, Miller, \& Brychan, 2004; Rovai, 2002; Wyatt, 2011).

The impact of blended learning on perceived and actual success in higher education has been examined numerously. Some studies have demonstrated outcomes that favoured blended learning over either a face to face or an online approach alone, demonstrated by higher course completion rates and increased learning outcomes (Gonzalez, 2014; Rovai \& Jordan, 2004). Boyle et al. (2003) reported significantly increased student grades and success rates for blended instruction compared with traditional face-to-face or online-only delivery over a six-month period. Giguere (2009) studied course completion rates over three consecutive academic years among 6,634 course enrolments in 137 face-to-face and 70 blended university courses. The results revealed that course completion rates were consistently higher in blended versus face-to-face courses.

However, several studies have noted that blended instruction may not be as effective as face to face or online instruction. For example, students received lower grades and complained about a larger workload associated with blended learning (Senn, 2008). The additional time and effort needed for students to overcome difficulties in blended learning might have interfered with their attention to detail and ability to complete the highest quality assignments possible (Senn, 2008). In the same vein, when comparing 167 college students who self-selected to enrol in blended, online, or face-to-face math courses, Ashby, Sadera, and McNary (2011) reported lower success rates in blended learning, as measured by students' final grades in math courses. Finally, Larson and Sung (2009) found no significant differences in students' exam scores and final grades when comparing delivery in face-to-face, online, and blended modes.

Blended learning is highly preferred by educators because of its student-centred approach, which is shifted from the traditional teacher centred approach. In this regard, it makes learners in the centre of learning process and students are encouraged to actively participate in discussions, forum and contribute towards the learning (Johan et al., 2014). By putting the learners' need first, the use of blended learning can also benefit students as it allows them to study at their own pace and based on their learning style. Students who are more competent will have extra time and have the opportunity to take part in enrichment activities while weaker students are able to repeat the learning activities until they are competent enough to proceed to next activities (McGinnis, 2005).

This of course encourage lecturers to provide balanced and equal guidance to all students, regardless of their abilities. Accordingly, blended learning is believed as a better alternative to elearning because it can help deal some issues including the lack of social interactions between 
students and the lack of holistic learning skills (Norasyikin, 2018; Tayebinik, 2012; Zhang \& Han, 2012).

The students, however, need to feel comfortable to work with computer applications and computer tools in order to reduce distress. Thus, an emerging reserch issue is on measuring students' acceptance towards this blended learning. This study explores level of acceptance of the learning management system by using the Technology Acceptance Model (TAM). It was originally proposed by Davis (1989), which aimed at expaining the computer usage behaviour in order to predict technology acceptance. The model proposes that the perceived usefulness and perceived ease of use predict users' acceptance of technology. Perceived usefulness is defined as "the degree to which a person believes that using a particular system would enhance his or her job performance and perceived ease of use is defined as the degree to which a person believes that using a particular system would be free of effort" (Davis: 1989).

The aim of this study is to examine students teachers' acceptance towards a blended learning approach using SPADA as the learning management system available at spada.untirta.ac.id. It has been conducted to measure the level of acceptance using SPADA which is combined with face to face learning.

\section{METHOD}

This study employes a quantitative approach and the survey method is adopted to collect the data. The data are collected using a set of questionnaire. The sample of this study consisted 118 undergraduate student teachers of English Department of Untirta who are enrolled in psycholinguistics course for 2019/2020 academic session.

In this course, the lecturer uses a blended learning approach where face to face learning is combined with online management learning system, called SPADA. It enables the lecturer to put the class materials, give assignments, quizzes, announcements, or create a forum for discussion. Then the students can log in and access it to download and read material, do assigment and quizezes as well as actively participate in a discussion forum.

After ten sessions, students are asked to fill out a questionnaire to examine the level of acceptance of the learning management system by using the Technology Acceptance Model (TAM). In addition, some students are interviewed to directly tell their learning experiences in face to face classroom and SPADA. The questionnaire comprises two sections, with regards the perceived usefulness and perceive ease of use. The items are adapted from Sun et.al (2008) with some minor changes which then measured by 1-5 Likert type scales items ranging from strongly disagree, disagree, neutral, agree to strongly agree.

\section{RESULT AND DISCUSSION}

Analyses are conducted on the Likert-type scale items from the survey to examine student teachers' acceptance toward blended learning (face to face and online learning). The result on perceived usefulness is described in table 1 . There are four items to measure perceived psefulness construct. The analysis shows that the average of perceived usefulness items is 4.18 which is classified on the above average category.

Table 1. Perceived usefulness of SPADA

\begin{tabular}{lcccccc}
\multicolumn{1}{c}{ Item } & $\begin{array}{c}\text { Strongly } \\
\text { Agree }\end{array}$ & Agree & Neutral & Disagree & $\begin{array}{c}\text { Strongly } \\
\text { Disagree }\end{array}$ & Average \\
\hline $\begin{array}{l}\text { SPADA enhances } \\
\text { learning effectiveness }\end{array}$ & 37 & 73 & 5 & 3 & 0 & 4.22 \\
\hline $\begin{array}{l}\text { SPADA improves } \\
\text { learning performance }\end{array}$ & 21 & 88 & 7 & 2 & 0 & 4.08 \\
\hline SPADA is useful & 28 & 85 & 3 & 2 & 0 & 4.18 \\
\hline
\end{tabular}




\begin{tabular}{llllllc}
\hline $\begin{array}{l}\text { SPADA enhances } \\
\text { learning productivity }\end{array}$ & 32 & 83 & 2 & 1 & 0 & 4.24 \\
\hline \multicolumn{1}{c}{ Total Average } & & & & & & $\mathbf{4 . 1 8}$ \\
\hline
\end{tabular}

To measure Perceived Ease of Use construct, four items are used. The result of data analysis in table 2 shows that the average of perceived ease of use items is 4.58 which then classified on the very high category.

Table 2. Perceived ease of use of SPADA

\begin{tabular}{lcccccc}
\hline \multicolumn{1}{c}{ Item } & $\begin{array}{c}\text { Strongly } \\
\text { Agree }\end{array}$ & Agree & Neutral & Disagree & $\begin{array}{c}\text { Strongly } \\
\text { Disagree }\end{array}$ & Average \\
\hline $\begin{array}{l}\text { Easy become skilful } \\
\text { using SPADA }\end{array}$ & 71 & 37 & 8 & 2 & 0 & 4.50 \\
\hline $\begin{array}{l}\text { Operate SPADA } \\
\text { would be easy }\end{array}$ & 79 & 26 & 11 & 2 & 0 & 4.54 \\
\hline $\begin{array}{l}\text { Easy to get SPADA to } \\
\text { do what I want }\end{array}$ & 83 & 25 & 7 & 3 & 0 & 4.59 \\
\hline $\begin{array}{l}\text { Find SPADA easy to } \\
\text { use }\end{array}$ & 89 & 24 & 4 & 1 & 0 & 4.70 \\
\hline \multicolumn{1}{c}{ Total Average } & & & & & & 4.58 \\
\hline
\end{tabular}

The data shows that the student teachers find that SPADA as the learning management system in the learning psycholinguistics is useful. This means that SPADA can help the students to enhance learning effectiveness, learning performance and learning productivity. From the perceived ease of use perspective, the respondents also find that SPADA is easy to use.

In addition to filling out an adapted TAM questionnaire, the respondents have been interviewed to get more insights from the students about their experiences. It is revealed that most students mentioned that SPADA is helpful and useful for them. They can easily get announcements from the teachers, download materials and slides, and work on the assignments/quizzes from the learning management platform. In addition, some students said that using SPADA is saving money for printing and paperless. The course materials and assignments do not need to be printed out since they can be accessed through their smartphones and notebooks.

Inspite of the usefulnes and ease of use, some negative impressions toward SPADA are also noted during the interview with the students. They find that students overwhelmed with the contents and educational activities. In addition, lecturers also should be careful on checking and reading the assignments because of the high possibility of plagiarism. This may influence fair assessment and work quality. Students also feel communication in face to face learning is more efficient since they directly get the feedback and make social interactions with the lecturer.

Several studies show that students' attitudes are influenced by the degree of communication in the blended course design (Conceicao \& Lehman, 2013; Fisher \& Baird, 2005; Gülbahar \& Madran, 2009). Specifically, their attitudes are affected by communication opportunities afforded by online courses, including instructor feedback and social interactions online with instructors and peers (Muilenburg \& Berge, 2005). It is conceivable that enhanced virtual communication and collaboration, and efficient instructor feedback for blended and online courses, would also benefit their learning.

Even though the online component is not mandatory in Untirta, most students felt it met their learning needs, online resources benefitted their learning, and most of the students said they could learn effectively via online instruction or would like to have more online learning opportunities. With flexible online access and additional support to meet students' individual needs outside of the classroom, the present findings confirm previous research reporting that students can benefit 
from the extra resources and support provided by a blended learning environment (Hauser et al., 2012; Larson \& Sung, 2009; Rovai \& Jordan, 2004; Senn, 2008).

The survey also reported the majority of the students have positive views towards blended learning approach. This could be because the use of e-learning suits their lifestyle and as digital natives, they highly prefer using technology for learning. As blended learning is a studentcantered approach where lecturers act as facilitators, the students feel that that blended learning allows them to participate actively in the teaching and learning process and they can use their technology skills in the learning process. At the same time, the extensive use of e-learning will help students develop higher technology skills required to keep up date with the information provided through the e-campus platform. This approach also presents a brand-new dimension in the teaching and learning of Arabic language as it creates an interactive learning platform which could student s' thinking more effectively. Consequently, psycholinguistics course lecturers could include blended learning as a learning approach as it allows students to learn through online mediated approach to complement face to face instruction. This will allow students to experience the best practice in both settings.

\section{CONCLUSION}

This study discusses student teachers' acceptance towards blended learning. Previous studies have demonstrated the various benefits of using blended learning and this study extent the previous studies by presenting student teachers' acceptance towards blended learning in psycholingsitics course. Technology Acceptance Model is adopted to examine perceived usefulness and perceived ease of use of SPADA.

The data analysis shows that students have a high level of acceptance towards SPADA as the learning management system for blended learning eventough they are new users of SPADA. One possible reasons is that the students are millennial generations who are native users and active on using technology. It is revealed that SPADA as the learning management system for blended learning has usefulness and ease to use for teaching and learning Psycholinguistics. Lecturers must carefully design the course content materials, actively use the learning management sytsem, and encourage the students to use of it. The negative impression raised by the students must be taken into consideration by managing the learning contents and assignments.

There are several limitations which need to be kept in mind when interpreting the results of the present study and considering future research. First, the study lasted for one semester and did not follow participants through to the end of the program. It is possible that student teachers ' attitudes and experiences might change over time. A longitudinal study with multiple assessment points would address this concern. Second, this study did measure the level of acceptance in general, not to mention the gender differences. It is suggested for future research to investigate the acceptace level based on gender differences. Third, time duration and the activities that students do when using SPADA are not considered. Thus, future research can consider those aspects which make the study more comprehenisive.

\section{REFERENCES}

Ashby, J., Sadera, W. A., \& McNary, S. W. (2011). Comparing student success between developmental math courses offered online, blended, and face-to-face. Journal of Interactive Online Learning, 10(3), 128-140. Retrieved from http://www.ncolr.org/jiol/issues/pdf/10.3.2.pdf

Boyle, T., Bradley, C., Chalk, P., Jones, R., \& Pickard, P. (2003). Using blended learning to improve student success rates in learning to program. Journal of Educational Media, 28(2-3), 165-178. doi:10.1080/1358165032000153160 
Conceicao, S., \& Lehman, R. (2013). Persistence model for online student retention. In J. Herrington, A. Couros \& V. Irvine (Eds.), Proceedings of EdMedia: World Conference on Educational Media and Technology 2013 (pp. 1913-1922). Association for the Advancement of Computing in Education. Retrieved from http://www.editlib.org/p/112230/

Fisher, M., \& Baird, D. E. (2005). Online learning design that fosters student support, selfregulation, and retention. Campus-Wide Information Systems, 22(2), 88-107. doi:10.1108/10650740510587100

Garrison, D. R., \& Kanuka, H. (2014). Blended learning: Uncovering its transformative potential in higher education. Internet and Higher Education 7, 95-105. doi:10.1016/j.iheduc.2004.02.001

Giguere, L. (2009). The impact of "virtualization" on independent study course completion rates: The British Columbia Open University experiment. Journal of Distance Education, 23(1), 49-70. Retrieved from http://www.ijede.ca/index.php/jde/article/view/470

Gonzalez, B. Y. (2014). Two-year community: a six-year review of student success in a biology course using lecture, blended, and hybrid methods. Journal of College Science Teaching, 43(6), 14-19.

Retrieved

from: http://www.nsta.org/store/product_detail.aspx?id=10.2505/4/jcst14_043_06_14

Gülbahar, Y., \& Madran, O. R. (2009). Communication and collaboration, satisfaction, equity, and autonomy in blended learning environments: A case from Turkey. International Review of Research in Open and Distance Learning 10(2). Retrieved from http://eric.ed.gov/?id=EJ844026

Hauser, H., Paul, P., \& Bradley, B. (2012). Computer self-efficacy, anxiety, and learning in online versus face-to-face medium. Journal of Information Technology Education, 11(1), 141-154. Retrieved from http://www.editlib.org/p/111497/

Hoskins, B. J. (2012). Connections, engagement, and presence. Journal of Continuing Higher Education, 60(1), 51-53. doi:10.1080/07377363.2012.650573

Larson, D. K., \& Sung, C. (2009). Comparing student performance: Online versus blended versus face-to-face. Journal of Asynchronous Learning Networks, 13(1), 31-42. Retrieved from http://files.eric.ed.gov/fulltext/EJ837556.pdf

Muilenburg, L. Y., \& Berge, Z. L. (2005). Student barriers to online learning: A factor analytic study. Distance Education, 26(1), 29-48. doi:10.1080/01587910500081269

Packham, G., Jones, P., Miller, C., \& Brychan, T. (2004). E-learning and retention: Key factors influencing student withdrawal. Education \& Training, 46(6), 335-342. doi:10.1108/00400910410555240

Pross, T., \& Barry, S. (2004). Reaching across the barriers. Kingston, Canada: Kingston Literacy. Retrieved from http://www.nald.ca/library/research/reachbar/cover.htm

Rovai, A. P. (2002). Sense of community, perceived cognitive learning, and persistence in asynchronous learning networks. Internet and Higher Education, 5(4), 319-332. doi:10.1016/S1096-7516(02)00130-6

Rovai, A. P., \& Jordan, H. P. (2004). Blended learning and sense of community: A comparative analysis with traditional and fully online graduate courses. International Review of Research in Open and Distance Learning, 5(2), 1-13. Retrieved from http://www.irrodl.org/index.php/irrodl/article/view/192/274

Senn, G. J. (2008). Comparison of face-to-face and hybrid delivery of a course that requires technology skills development. Journal of Information Technology Education, 7, 267283. Retrieved from http://jite.org/documents/Vol7/JITEv7p267-283Senn309.pdf 
Wyatt, L. G. (2011). Non-traditional student engagement: Increasing adult student success and retention. Journal of Continuing Higher Education, 59(1), 10-20. 10-20. doi:10.1080/07377363.2011.544977

Zacharakis, J., Steichen, M., Diaz, D. S., \& Glass, D. (2011). Understanding the experiences of adult learners: Content analysis of focus group data. Adult Basic Education and Literacy Journal, 5(2), 8495. Retrieved from http://eric.ed.gov/?id=EJ936696 